\section{Cucumber Germplasm Resistant to Cladosporium cucumerinum}

\author{
Young Hoon Park \\ Department of Horticulture, 1575 Linden Drive, University of Wisconsin, \\ Madison, WI 53706
}

Michael. J. Havey ${ }^{1}$

Vegetable Crops Unit, Agricultural Research Service, U.S. Department of Agriculture, Department of Horticulture, 1575 Linden Drive, University of Wisconsin, Madison, WI 53706

\begin{abstract}
Scab (caused by Cladosporium cucumerinum Ell. \& Arth.) is an important disease of cucumber (Cucumis sativus $L_{\text {.) }}$, and the only source of resistance traces back to the cultivar Maine No. 2. We inoculated hypocotyls of 188 cucumber accessions with one strain of the scab fungus to identify other sources of scab resistance. Accessions NSL5731, $255933,264666,264667,306785,342951,354952,458845$, and 535881 showed no symptoms. Plants in accession 525075 showed a continuous phenotypic distribution for reaction to scab; all other accessions were susceptible.
\end{abstract}

Scab is an important disease of cucumber, and was a serious threat to cucumber production in the northern United States, Canada, and northern Europe before 1950. Bailey (1939) developed the scab-resistant cultivar Maine No. 2, which Bailey and Burgess (1935) and Walker (1950) used to demonstrate that resistance was controlled by a dominant allele at the $C c u$ locus (Xie and Wehner, 2001). To the knowledge of the authors, all current scabresistant cucumbers trace back to 'Maine No. 2' (Walker et al., 1953). There is no evidence of race specialization in the scab fungus, and this single source of resistance has remained effective over many years. Nevertheless, it is important to identify other sources of scab resistance in the event of failure of the presently used source of resistance. In addition, the dominance of scab resistance and the ease of seedling evaluations (Abul-Hayja, 1975; Vakalounakis and Williams, 1989) make scab resistance an excellent phenotypic marker for hybridity.

\section{Materials and Methods}

Phenotypic evaluations for scab resistance were conducted using hypocotyl inoculations as described by Abul-Hayja (1975). A total of 188 cucumber plant introductions (PIs) were selected, taking into account maximum geographical diversity [all PIs were listed by Park (2002)]. Seeds were obtained either from

Received for publication 16 Sept. 2002. Accepted for publication 4 Feb. 2003. Names are necessary to report factually on available data; however, the U.S. Dept. of Agriculture (USDA) neither guarantees nor warrants the standard of the product, and the use of the name by USDA implies no approval of the product to the exclusion of others that may also be suitable.

${ }^{1}$ USDA Research Geneticist and Professor of Horticulture; to whom reprint requests should be addressed.E-mail: mjhavey@wisc.edu the North Central Regional Plant Introduction Station (Ames, Iowa) or National Seed Storage Laboratory (Fort Collins, Colo.). Cucumber seeds were sown in steam-sterilized coarsegrade vermiculite in wooden flats $(52 \times 36 \times 7$ $\mathrm{cm})$. Each flat contained 10 rows. Twenty-five seeds per each PI were sown in each row with resistant (Gy14) and susceptible (Straight 8) controls in a center row. The flats were placed on a heated bench at $32{ }^{\circ} \mathrm{C}$ and covered with wet newspapers to ensure rapid and uniform germination. The seedlings were inoculated on the fifth day after seeding, when the cotyledons were just expanded.
Scab strain MJH \#662 was stored at $4{ }^{\circ} \mathrm{C}$ on potato dextrose agar (PDA) under mineral oil. A piece of mycelium was aseptically removed and placed on a petri plate with PDA and incubated at $20^{\circ} \mathrm{C}$ in the dark. For spore collection, 3-4 mLs of distilled water were added to 7- to 10-day-old scab culture; the culture was scraped with a bacteriological loop to dislodge spores; and the liquid was filtered through a single layer of cheesecloth. Spores were counted with a hemacytometer and concentrations adjusted to $4 \times 10^{5}$ spores $/ \mathrm{mL}$ with sterile distilled water. The inoculum was sprayed onto hypocotyls until runoff, using an airbrush (Badger model 100, Franklin Park, Ill.). Inoculated plants were incubated for 48 $\mathrm{h}$ at $20{ }^{\circ} \mathrm{C}$ in the dark at $100 \%$ relative humidity. Flats were then placed on the greenhouse bench for $3 \mathrm{~d}$ and scored $5-7 \mathrm{~d}$ after inoculation using a 0 to 9 scale, where $0=$ no symptoms; $1=$ blisters on hypocotyls; $3=$ restricted tan lesion on hypocotyls; $5=$ larger tan lesion on hypocotyls; 7 = large sunken lesion on hypocotyls; and 9 = collapsed plant (Abul-Haya, 1975). Mean disease severity indices (DSI) of 3 or less were considered resistant; those $>5$ were considered susceptible. Disease evaluations were replicated for PI accessions that had a mean DSI $<3$ in the first inoculation.

\section{Results and Discussion}

Susceptible plants developed large sunken lesions on hypocotyls, and most seedlings collapsed 4-5 d after inoculation. Resistant plants showed either no symptoms or shallow tan lesions on hypocotyls. The resistant control (Gy14) had a mean DSI $=0.0$ for all inoculations. The susceptible control (Straight 8) was
Table 1. Phenotypic distributions in cucumber plant introductions showing relatively high frequencies of scab resistance (mean disease severity index $\leq 3.0$ ).

\begin{tabular}{|c|c|c|c|c|c|c|c|}
\hline \multirow[b]{2}{*}{ Accession } & \multirow[b]{2}{*}{ Origin } & \multicolumn{6}{|c|}{ Nos. of plants with disease severity index ${ }^{2}$} \\
\hline & & 0 & 1 & 3 & 5 & 7 & 9 \\
\hline$\overline{197086}$ & India & 21 & & & & 1 & 4 \\
\hline 229808 & Canada & 29 & 2 & 1 & & 1 & 5 \\
\hline 255933 & Netherlands & 25 & & & & & \\
\hline 264664 & Germany & 37 & & & 1 & 1 & \\
\hline 264665 & Germany & 31 & 1 & & & & 2 \\
\hline 264666 & Germany & 42 & & & & & \\
\hline 264667 & Germany & 43 & & & & & \\
\hline 264668 & Germany & 30 & 1 & 3 & & 1 & 8 \\
\hline 283899 & Czech Republic & 35 & 1 & & 1 & 4 & 5 \\
\hline 285606 & Poland & 35 & & & 2 & & 8 \\
\hline 285609 & Poland & 14 & & & & & 5 \\
\hline 306785 & Canada & 9 & & & & & \\
\hline 314425 & Former USSR & 41 & & & & & 3 \\
\hline 324239 & Sweden & 19 & & & & 1 & 5 \\
\hline 342951 & Denmark & 46 & & & & & \\
\hline 354952 & Denmark & 50 & & & & & \\
\hline 379285 & Macedonia & 33 & & & & 1 & 5 \\
\hline 458845 & Russia & 38 & & & & & \\
\hline 481614 & Bhutan & 8 & 18 & 8 & 3 & & 4 \\
\hline 481617 & Bhutan & 17 & 5 & & & & \\
\hline 500359 & Zambia & 31 & & & & & 1 \\
\hline 525075 & Mauritius & 17 & 4 & 13 & 2 & 2 & 8 \\
\hline 535881 & Poland & 48 & & & & & \\
\hline Ames 19221 & Ukraine & 10 & 5 & 5 & 2 & 1 & 11 \\
\hline Ames 20206 & India & 11 & 3 & & 2 & 2 & 4 \\
\hline Ames 21224 & USA & 8 & 14 & 4 & & 5 & 5 \\
\hline NSL 5731 & Unknown & 22 & & & & & \\
\hline
\end{tabular}

${ }^{\mathrm{z}}$ Disease severity indices are described in Materials and Methods. Numbers of plants are the sum of two replications, except 285609 and 306785 , which were evaluated once. 
rated higher than mean DSI $=8.2$, except for two flats with mean DSI $=6.0$ and 7.7. Among $188 \mathrm{PI}$ accessions, 27 had high frequencies of resistant plants (mean DSI <3) (Table 1) and 161 had primarily susceptible plants (mean DSI >5). All phenotypic distributions were submitted to the USDA germplasm resource information network (GRIN) and reported in Park (2002). Numerous PI accesions had both resistant and susceptible plants and were likely segregating for these phenotypes. Some PIs showed continuous phenotypic distributions, but these tended to occur in inoculations in which the susceptible controls had relatively low ratings (mean DSIs between 6.0 and 7.7). PI 525075 showed a continuous phenotypic distribution, even though all susceptible controls were killed and the other PIs simultaneously inoculated showed discontinuous phenotypes. For eight PI accessions (NSL 5731, 255933,
264666, 264667, 306785, 342951, 354952, 458845, and 535881), all plants showed no symptoms $(\mathrm{DSI}=0.0)$. PI accessions possessing only resistant plants or segregating for scab resistance tended to be from northern countries and represent important additional sources of scab resistance. However, these accessions may carry the scab-resistance gene originating from 'Maine No. 2'. Among the PI accessions showing high levels of scab resistance (Table 1), the earliest entry into the USDA plant germplasm system was 197086, obtained from India in 1951, well after Bailey (1939) had developed the scab-resistant cultivar Maine No. 2.

\section{Literature Cited}

Abul-Hayja, Z.M. 1975. Multiple disease screening and genetics of resistance in cucumber. $\mathrm{PhD}$ Diss.. Univ. of Wisconsin-Madison.

Bailey, R.M. 1939. A scab resistant home garden cu- cumber. Maine Agr. Expt. Sta. Misc. Publ. 554.

Bailey, R.M. and I.M. Burgess. 1935. Breeding cucumbers for resistance to scab. Proc. Amer. Soc. Hort. Sci. 32:474-476.

Park, Y.H. 2002. Molecular tagging of loci conditioning potyvirus resistances and mitochondrial transmission studies in cucumber (Cucumis sativus L.). PhD Diss., Univ. of Wisconsin-Madison.

Vakalounakis, D.J. and P.H. Williams. 1989. Acotyledon screen for resistance to scab (Cladosporium cucumerinum) in cucumber (Cucumis sativus) seedlings. Ann. Appl. Biol. 115:443-450.

Walker, J.C. 1950. Environment and host resistance in relation to cucumber scab. Phytopathology 40:1094-1102.

Walker, J.C., C.F. Pierson, and A.B. Wiles. 1953. Two new scab-resistant cucumber varieties. Phytopathology 43:215-217.

Xie, J. and T.C. Wehner. 2001. Gene list 2001 for cucumber. Rpt. Cucurbit Genet. Coop. 24: $110-136$. 